\title{
The Coming of Islam to Balkh
}

\author{
Arezou Azad and Hugh Kennedy
}

\section{1 \\ Introduction}

The coming of the Muslim armies to Central Asia from 650 onwards and the subsequent settlement of Arabs in and around the main urban centers had a profound and lasting effect on the urban topography of the area. The reconfigured city of Balkh extended beyond the city walls to the surrounding countryside, fulfilling a central role in commercial, religious, military and administrative activities. Urban institutions and structures thus served to establish Balkh's position in the region and ensure control of the surrounding populations which contributed to the city's role. There are four major urban centers in greater Khurāsān - Balkh, Bukhara, Merv, and Samarqand. Of these, Balkh, until recently, has been the least understood and the least researched. ${ }^{1}$ The archaeological site of pre-modern Balkh is situated in northern Afghanistan. Much of the site remains unaffected by modern development and open for archaeological and historical investigation. The purpose of this joint paper is to set the developments at Balkh, in so far as we can determine them, in the wider context of the history of urbanism in Central Asia and to give some indication how further archaeological research might shed light on the evolution of the city in the early Islamic period.

The sources we have at our disposal are both textual and archaeological. The textual material consists mainly of narratives that are useful to the topic of this chapter. ${ }^{2}$ Bactrian documents discovered in the 1990 are an invaluable source

1 Much headway has been made thanks to the Balkh Art and Cultural Heritage project (BACH) run out of the University of Oxford, 2011-2015. See www.balkhheritage.org (accessed: 27 July 2016).

2 For previous studies on the history of the site, see Paul Schwarz, "Bemerkungen zu den arabischen Nachrichten über Balkh," in Oriental Studies in Honour of Cursetji Erachji Pavry, ed. Jal Dastur Cursetji Pavry (London: Oxford University Press, 1933), 434-443; Florian Schwartz, 
for Kushano-Sasanian and early Islamic Bactria in a rural metropolis located $130 \mathrm{~km}$ to the SE of Balkh within the Tukhāristān region of which Bactra (Arabicised to Balkh after the Islamic conquests) was the capital. They deal with an array of issues, including keeping the peace between feuding parties, the purchase of land or goods, slave manumission, gifts, leases, declarations of trust (or impost?), loan receipts, and marriage. However, they make all but a single tangential reference to the city of Balkh, and will, therefore, not feature in this chapter. ${ }^{3}$ The narrative sources span various languages, including Persian, Arabic and Chinese. An early source is the Chinese pilgrim's account by Xuanzang who travelled to Bactra in the 63 os only briefly before the first Muslim incursions into the city. He gives us a particularly detailed account of the city's main Buddhist temple (Sk. stupa), called Naw Bahār, and its monastery (Sk. vihara) and hundreds of domed shrines to the Buddhist saints (arhats). Ninth and tenth-century Muslim geographers give us critical details on Balkh's topography in the first centuries after the arrival of Islam to Balkh. They include al-Ya'qūbī (d. after 292/905), Ibn al-Faqīh (d. after 292/905), al-Ișțakhrī (ca. 338/ 950), al-Mas'ūdī (ca. 344-345/955-6), Ibn Ḥawqal (ca. 378/988), al-Muqaddasī (d. after 380/99o), and al-Idrīsì (ca. 548/1154), as well as the anonymous Persian Hudūd al-ălam (ca. 372/982). ${ }^{4}$ Parallel data on Balkh can be found in chroni-

Balh und die Landschaften am oberen Oxus: Hurasan III, Sylloge Numorum Arabicorum Tübingen XIVc (Tübingen: Wasmuth Verlag, 2002); Elhameh Meftah, Jughrāfiyā-yi tārīkh-i Balkh wa Jayhūn wa muzāfāt-i Balkh (Tehran: Institute for the Humanities and Cultural Studies, 1367/1997).

3 What the silence on Balkh does signify, though, is the relative autonomy from Balkh of the rural metropolises in the wider region. The documents have been translated and published in Nicholas Sims-Williams, Bactrian Documents from Northern Afghanistan, I: Legal and Economic Documents, revised edition, Studies in the Khalili Collection, vol. 3, Corpus Inscriptionum Iranicarum, part. 2, vol. 6. (Oxford:The Nour Foundation in association with Azimuth Editions and Oxford University Press, 2012); and Geoffrey Khan, Arabic Documents from Early Islamic Khurasan, Studies in the Khalili Collection, vol. 5 (London: Nour Foundation in association with Azimuth Editions, 20o6). For a recent historical study of the documents, see Arezou Azad, "Living Happily Ever After: Fraternal Polyandry, Taxes and 'the House' in Early Islamic Bactria," Bulletin of the School of Oriental and African Studies 79, no. 1 (2016): 33-56.

4 Abū al-Abbās Aḥmad b. Abī Ya'qūb al-Ya'qūbī, Kitāb al-Buldān, ed. Michael Jan de Goeje (Leiden: Brill, 1892 (186o)); Ibn al-Faqīh, Kitāb al-Buldān, ed. Michael Jan de Goeje (Leiden: Brill, 1967), and facs. ed. in Ibn al-Faqīh, Collections of Geographical Works by Ibn al-Faqïh, Ibn Fadlān, Abū Dulaf al-Khazrajī, ed. Fuat Sezgin (Frankfurt am Main: Institute for the History of Arabic-Islamic Science, 1987); Abū Isḥāq Ibrāhīm b. Muḥammad al-Ișțakhrī, Kitāb Masālik al-mamālik, ed. Michael Jan de Goeje (Leiden: Brill, 1927); Abū al-Ḥasan 'Alī b. al-Ḥusayn al-Mas'ūdī, Kitab al-Tanbīh wa al-ishrāf, 2nd ed., ed. Michael Jan de Goeje (Leiden: Brill, 1893-1894); Abū al-Qāsim b. 'Alī Ibn Ḥawqal, Șūrat al-arḍ, ed. Michael Jan de Goeje (Leiden: Brill, 1873), trans. Johannes Hendrik Kramers and Gaston Wiet as: Configuration de la Terre 
cles, such as those of al-Balādhurī (d. 279/892), al-Ṭabarī (d. 310/923), Bal'amī (d. 363/974), Gardīzī (ca. 440-443/1049-1052) and Bayhaqī (470/1077). ${ }^{5}$ A local historical source known as the Fadā'il-i Balkh ('The Merits of Balkh') is particularly important because it is the earliest local history that survives, written in Arabic in 610/1214, and adapted into Persian in $676 / 1278 .{ }^{6}$ Although it is mainly a prosopographical work about Islamic scholars, it nonetheless contains a few details on Balkh's medieval topography that cannot be found anywhere else. ${ }^{7}$

The archaeological evidence for Balkh is extensive - for much of the ancient site remains unbuilt on - but little researched and difficult to use. Much of the archaeological evidence has been collected since the 1920 s by the Délégation Archéologique Française en Afghanistan (DAFA). Until 2011, DAFA was little concerned with the Islamic period of Balkh, while searching for Alexander the Great's city of Bactra. DAFA and other archaeologists published some impor-

(Beirut: Commission Internationale pour la Traduction des Chefs-d' œuvre, 1964); Shams alDīn Abū 'Abd Allāh Muhammad b. Aḥmad al-Muqaddasī, Kitāb Aḥsan al-taqāsìm fì márifat al-'aqālìm, ed. Michael Jan de Goeje (Leiden: Brill, 19o6), trans. Basil Collins et al. as: The Best Divisions for Knowledge of the Regions (Doha, Qatar and Reading: Centre for Muslim Contribution to Civilization, and Garnet, 1994); Anonymous, Hudūd al-ālam, revised edition, ed. Maryam Mīr-Aḥmadī and Ghulām-Riḍā Warharām (Tehran: Chāpkhāna-yi Dānishgāh-i al-Zahrā', 1383/2004-2005); and Abū 'Abd Allāh Muḥammad b. Muḥammad al-Idrīsī, Description de l'Afrique et de l'Espagne: texte arabe avec une tr., des notes et un glossaire par R. Dozy et M.J. de Goeje (Kitāb Nuzhat al-mushtāqfí ikhtirāq al-āfāq) (Leiden: Brill, 1866). Also Guy Le Strange's synthesis of much of this material in his Lands of the Eastern Caliphate (Cambridge: University Press, 1905), 420-423.

5 Aḥmad b. Yahyāa al-Balādhurī, Futūḥ al-buldān, ed. Michael Jan de Goeje (Leiden: Brill, 1866), trans. Francis C. Murgotten as: The Origins of the Islamic State: Being a Translation from the Arabic, Accompanied with Annotations, Geographic and Historic Notes of the Kitâb Futûh AlBuldân of Al-Imâm Abū-l 'Abbâs Ahmad Ibn-Jâbir Al-Balâdhuri, 2 vols. (New York: Columbia University Press, 1924); al-Ṭabarī, Ta’rīkh al-rusul wa-l-mulūk, 3 vols., ed. Michael Jan de Goeje et al. as: Annales quos scripsit Abu Djafar Mohammed ibn Djarir at-Tabari, 15 vols. (Leiden: Brill, 1879-1901); Abū 'Alī Muḥammad b. Muḥammad Bal'amī, Tārīkh-i Bal'amī, eds. Parvīn Gunābādī and Muḥammad Taqī Bahār (Tehran, Kitābfurūshī-yi Zavvār, 1353/1974); Abū Saīd 'Abd al-Ḥayy b. al-Ḍaḥhāk b. Maḥmūd Gardīzī, Zayn al-akhbār, ed. 'Abd al-Ḥayy Ḥabībī (Tehran: Intishārāt-i Bunyād-i Farhang-i İrān, 1347/1968), trans. Edmund Bosworth as: The Ornament of Histories: A History of the Eastern Islamic lands AD 650-1041: The Original Text of Abû Sa îd Abd al-Hayy Gardīzī, BIPs Persian Studies Series 10 (London: I.B. Tauris, 2011); Abū al-Faḍl Muhammad b. Ḥusayn Bayhaqī, Tārīkh-i Bayhaqī, ed. 'Alī Akbar Fayyāḍ (Tehran: Kitābkhānayi Millī-yi İrān, 1383/2004-2005), trans. Edmund Bosworth and Mohsen Ashtiany as: The History of Beyhaqi: The History of Sultan Mas'ud of Ghazna, 1030-1041, 3 vols. (Boston, MA: Ilex Foundation, 2011).

6 For details, see Arezou Azad, "The Faḍāill-i Balkh and its Place in Islamic Historiography," IRAN - Journal of the British Institute of Persian Studies 50 (2012): 79-102.

7 Shaykh al-Islām al-Wā’iz, Fa đậ̉il-i Balkh, ed. 'Abd al-Ḥayy Ḥabībī (Tehran: Intishārāt-i Bunyādi Farhang-i İrān, 1350/1971). 
tant reports from the 1940s to the 196os, notably those of Alfred Foucher in the 1940s, and Daniel Schlumberger, Rodney Young, Jean-Claude Gardin, and Marc Le Berre in the 195 os and '6os. ${ }^{8}$ In another relevant source, Ludwig Adamec in the 1970 edited a declassified 1914 gazetteer of Afghanistan compiled by the British General Staff of the Army Headquarters in India. The volume on 'Mazāri Sharif and North-Central Afghanistan' provides topographical information on Balkh. ${ }^{9}$ Warwick Ball compiled an archaeological gazetteer that includes maps and details of archaeological finds in Afghanistan's wider Balkh area. ${ }^{10}$ DAFA's research was disrupted by the Soviet occupation of Afghanistan (1978-1987), the two civil wars (1989-1996) and Taliban rule (1996-20o1) but it resumed archaeological excavations at Balkh in 2005. The findings from the digs since 2005 have not yet been systematically analyzed or published, but a summary is expected in a forthcoming volume."

At the heart of the site lies a large circular area (known today as the Bālā Hișār) of approximately one kilometer in diameter, enclosed by a high mudbrick wall, with a raised citadel at the south end. Beyond that is a series of walls,

8 Alfred Foucher, La Vieille route de l'Inde de Bactres à Taxila, vol. 1 (Paris: Les Éditions d'art et d'histoire, 1942-1947); Daniel Schlumberger, "La prospection archéologique de Bactres (printemps 1947)," Syria 26 (1949): 173-19o; Rodney Young, "The South Wall of Balkh-Bactra," American Journal of Archaeology 59 (1955): 267-276; Jean-Claude Gardin, Céramiques de Bactres: Mémoires de la Délégation Archéologique Française en Afghanistan XV (Paris: Libr. C. Klincksieck, 1957); and Marc Le Berre and Daniel Schlumberger, "Troisième partie - Observations sur les remparts de Bactres," in Monuments Préislamiques d'Afghanistan, eds. Bruno Dagens, Marc Le Berre and Daniel Schlumberger (Paris: Librairie G. Klincksieck, 1964), 41-6o. For a fuller listing of the various published archaeological reports up to 1982 on Balkh/Bactria, see Warwick Ball, Archaeological Gazetteer of Afghanistan, vol. 2 (Paris: Éditions recherche sur les civilisations, 1982), 47-49, plans 6, 7.1 and map 81 (a revised version is currently in progress).

$9 \quad$ Ludwig Adamec lists his sources 'collected by the British Indian Government and its agents since the early nineteenth century, in Historical and Political Gazetteer of Afghanistan: Mazar-i-Sharif and North-Central Afghanistan, vol. 4 (Graz, Austria: Akademische Druck- u. Verlagsanstalt, 1979), xii, xiv-xvi.

10 Ball, Archaeological Gazetteer.

11 The volume, entitled Balkh, 'Mother of Cities': Research into a Central Asian Urban Landscape of the Early Islamic Age will be published by I.B. Tauris. Some reporting of preliminary findings have been published in the Comptes rendus des séances / Académie des Inscriptions et Belles-Lettres. See Roland Besenval, Paul Bernard and Jean-François Jarrige, "Carnet de route en images d'un voyage sur les sites archéologiques de la Bactriane afghane (mai 2002)," Comptes Rendus des Séances de l'Académie des Inscriptions et BellesLettres 146, no. 4 (2002): 1385-428; Paul Bernard, Roland Besenval and Philippe Marquis, "Du « mirage bactrien » aux réalités archéologiques: nouvelles fouilles de la délégation archéologique française en Afghanistan (DAFA) à Bactres (2004-2005)," Comptes Rendus des Séances de l'Académie des Inscriptions et Belles-Lettres 150, no. 2 (2006): 1175-248. 
some sub-rectangular, others winding and serpentine that enclose a larger area (rabad). There are medieval accounts that a massive outer wall had enclosed the whole Balkh oasis, but only anectodal archaeological evidence has been found for this. Al-Ya'qūbī notes, "A huge wall encloses the village farms (diy $\left.\bar{a}^{c}\right)$ and cultivated lands of Balkh ... and outside the wall there is no cultivation or farms or villages, only the sands."12 In the suburban area there are a number of important mounds, including the site now thought to be the Buddhist stupa of Naw Bahār, and a site known as Tepe Zargarān ('Hill of the Goldsellers,' for this and other sites mentioned). DAFA has drawn up sketch maps of the site, with suggested sequences of the major structural elements. ${ }^{13}$ According to Rodney Young, Marc Le Berre categorized old Balkh's sketch maps into 'Bactres I' which is vaguely determined as pre-Islamic Bactra and consists of the elevated Bālā Hiṣāa (lit. "high fort"); 'Bactres IA' which is pre-Islamic and early Islamic Bactra and includes Bactres I and the southern extension in the lowland (the rabad); 'Bactres II' which represents Islamic Balkh up to the Mongols and includes Bactres IA and an eastern extension of the rabad, and 'Bactres III' as the post-Timurid city to the west of the rabad (during which time 'Bactres II' was abandoned). ${ }^{14}$

The division of the city in the way that Le Berre did is problematic for two reasons. First, the evidence that survives comes from a very limited set of evidence taken from a small number of trenches, and it is therefore, impossible to extrapolate onto the entire city. Secondly, and most importantly, the divisions

12 al-Ya'qūbī, Buldān, 116.

13 Foucher drew up the first map which he divided into 'modern' and 'old,' basing himself on archaeological evidence from Balkh's Bālā Hișār mound and the stratigraphy of wall ramparts (Foucher, Vieille route, $73^{-75}$ ).

14 No major pre-Islamic city complex has been found to the dismay of the early French archaeologists, like Alfred Foucher, while major sites have been uncovered in adjacent provinces in the north. Ai Khanoum is the main Hellenistic site, dug up in Takhar province to the NE of Balkh. Surkh Kotal is a Kushan site in Baghlān province just to the south of Balkh. The main Buddhist site is at Bamiyān soth of Baghlān. Paul Bernard et al., Fouilles d'AïKhānom (Paris, Klincksieck, 1973-); Gérard Fussman and Daniel Schlumberger, Surkh Kotal en Bactriane (Paris, Diffusion de Boccard, 1983-199o). Soviet explorations at Tilla Tepe in Dilbarjīn (in Jūzjān district, west of Balkh) by Viktor Sarianidi uncovered the gold hoards that have been touring the museums of the world over the past decade. See Viktor Sarianidi, The Golden Hoard of Bactria (New York: H.N. Abrams, 1985). Two important Buddhist sites on the Tajik side of Bactria and excavated by Soviet archaeologists are at Ajina Tepe, 12 kilometers east of Kurgan-Tiube; and Kalai Kafirnigan monastery. See Boris Litvinskij, The Buddhist Monastery of Ajina Tepa (Rome: IsIAO, 2004); and idem, "KalaiKafirnigan: Problems in the Religion and Art of Early Mediaeval Tokharistan," East and West 31 (1981): 35-66. 
are limited to the intramural spaces of the city. Given that some of the city's most important pre-Islamic and early Islamic sites, such as, the Naw Bahār and the Nuh Gunbad (see below) are located outside of the city walls, Le Berre's model is incomplete and most probably incorrect.

The archaeology of Balkh reflects many of the problems involved in using the archaeological evidence of Central Asian cities for the reconstruction of urban topography. ${ }^{15}$ Very little stone was employed in the buildings of the cities of Central Asia in this period. The main building materials used were mud-brick, either in brick form or in larger molded blocks. There was also extensive use of wood. Decoration was largely carried out in stucco plaster and the exterior tile-work so characteristic of the area in the post-Mongol period was virtually unknown before the end of the twelfth century. Fired brick was much less used and even when it was, it was usually robbed out for reuse.

The nature of the archaeological evidence seriously restricts the types of information that it can reveal. Typically we can see the outlines of citadels and of city walls giving an idea, grosso modo, of the area of settlement. Dating of these massive structures can sometimes be determined by excavation, especially if the excavation produces coins or diagnostic pottery in a clear archaeological context. It is much more difficult to recognize individual buildings and still more so to say anything about their architectural forms. It is only in the case of the few surviving structures made of fired brick that we can see anything of the architectural detail.

In Balkh, the Nuh Gunbad stands out as a fired brick structure that has recently been dated to as early as the eighth century. It is a nine-domed structure that is a common pre-Islamic Iranian building form. A mihrāb found at the site seems to indicate that it was used as a mosque, making it possibly the earliest mosque in the Islamic east. ${ }^{16}$ However, none of the Arab geographers mentions it, and the local history of Balkh, the Fadäil-iBalkh written in the late twelfth century only mentions a nuh gunbadān in passing without specifying that it might be a mosque. Lisa Golombek identified the stucco carvings, a distinctive style with a vocabulary of motifs consisting of grape-leaves, vinescrolls, palmettes, and fir-cones, as being best represented in Samarra, the Iraqi city

15 For an overview of the development of Iranian cities in the early Islamic period, see Hugh Kennedy, "From Shahristan to Medina," Studia Islamica 102-103 (2006): 5-34.

16 Chariyar Adle, "Communication: la mosquée Hâji Piyâdah/Noh Gonbadân à Balkh (Afghanistan), un chef d' œuvre de Fazl de Barmecide construit en 178-179/794-795?” Comptes Rendus des Séances de l'Académie des Inscriptions et Belles-Lettres 2001, no. 1 (2011): 565-625. 
$125 \mathrm{~km}$ north of Baghdad founded by the 'Abbāsid caliph al-Mu'tasim (r. 218$227 / 833-842$ ). The question remains open whether the transmission of decorative style went from west to east, or vice versa. ${ }^{17}$

\section{3} The Early History of Balkh to the End of the Umayyads

Balkh is located in northwestern Afghanistan, an oasis sandwiched between the Oxus River and Hindukush mountains and watered by the Balkhāb river and canals flowing from the mountains located in the south. Bactra was the capital of the pre-Islamic Bactria which at its height included the eastern Iranian lands, as well as, southern Tajikistan, the lands south of the Hindukush and northern India (modern-day Pakistan and the north-west frontier). Bactra and Bactria together became known in the Persian and Arabic sources as 'Balkh.'

The first surviving textual mention of ancient Bactria is found in the Vendidad section of the Zoroastrian holy book, the Avesta. ${ }^{18}$ We have accounts of Bactria during the Median period (seventh to sixth century BCE), and documentary evidence of its relations with the Achaemenids (sixth to fourth century $\mathrm{BCE}$ ) and the Hellenistic conquerors (fourth to first century ВСЕ). ${ }^{19}$ Amongst the various nomadic invaders, the Kushans achieved supremacy, bringing Buddhism to Bactra in the second century $\mathrm{CE}$, and building the city's Naw Bahār shrine and monastery. Bactria was eventually integrated into the Sasanian realm. Ardashir I (r. 224-242) is said to have visited Balkh when establishing his rule ${ }^{20}$ and Bahram Gur (r. 420-438) appointed his brother as governor of Khurāsān and assigned Balkh to him as his capital. ${ }^{21}$ But the Kushans retained much of the governing powers in Bactra. ${ }^{22}$ After a period of rule by

17 Lisa Golombek, "The Abbasid Mosque at Balkh," Oriental Art 15 (1969): 177. The 'Masjid-i Chahār Sutūn' at Tirmidh has the same nine-domed floorplan. Robert Hillenbrand, Studies in Medieval Islamic Architecture (London: Pindar Press, 2006), 2: fig. 19.

18 Fritz Wolff, ed., Avesta: die heiligen Bücher der Parsen (Strassburg: Karl J. Trübner, 1910, paras. 1.6-1.7), 317-318. The Avesta known to us today was written down under the Sasanians during the fourth century.

19 Ctesias of Cnidus, "Persica," in Photius, Bibliothèque, ed. René Henry (Paris: Les Belles Lettres, 1959-1991); Jan Stronk, Ctesias' Persian History (Düsseldorf: Wellem, 2010); Joseph Naveh and Shaul Shaked, eds. and trans., Aramaic Documents from Ancient Bactria: (Fourth Century B.C.E.): From the Khalili Collections (London: Khalili Family Trust Publication, 2012).

$20 \quad$ al-Ṭabarī, Tårīkh, 2:819.

21 al-Ṭabarī, 866.

22 Nicholas Sims-Williams, New Light on Ancient Afghanistan: The Decipherment of Bactrian, 
the 'White Huns' (Kidarites, Chionites and Hephthalites) in the fifth century, Bactra was formally back in Sasanian hands until the Muslim conquests.

The first Muslim "crossing of the [Oxus] river" was achieved in 22/642-643 during the time of the caliph 'Umar (r. 13-23/634-44) by al-Ahnaf b. Qays, according to the author of the Fadăail-i Balkh (FB). Al-Tabarī adds that alAhnaf appointed his nephew to rule, and he is said to have received mihragān gifts from the notables of the city, much to his surprise. ${ }^{23}$ As so often in the conquests of Central Asia, the process had to be repeated several times. $F B$ states that Balkh was besieged in 32/652-653 by Saìd, the son of the fourth caliph Uthmān. Al-Ya'qūbi, by contrast says that the city was taken by 'Abd alRạ̣mān b. Samura (fl. 43/663) in the reign of Mu'āwiya I (r. 41-6o/661-68o), ${ }^{24}$ and al-Balādhurī attributes the conquest to the Khurāsān governor Qays b. al-Haytham al-Sulamī (fl. 41/661) "who destroyed its Naw Bahār."25 Al-Ya'qūbī describes Balkh as the biggest city of Khurāsān at the time of the conquests and says that a certain "Ṭarkhān, the king (malik) of Khurāsān" had settled there. ${ }^{26}$ The Arab conquerors are said to have come from the city of Küfa, and Balkh was "one of the conquests of the Küfans" with 400,00o dirhams being agreed upon as tribute. ${ }^{27}$ Whatever the reality of the original "conquest," the inhabitants soon rejected Muslim rule, and in 51/671 we find al-Rābi ' b. Ziyād alHaârithī conquering the city peacefully, that is coming to an agreement with the inhabitants "since they had locked (the city) after al-Ahnaf b. Qays had made peace with them."28

It is not clear when permanent Muslim settlement began in Balkh. The presence of an ispahbadh (pre-Islamic army chief) in the city in 90/708-709 and again in 91/709-710 implies that there were still Iranian, non-Muslim officials

An Inaugural Lecture Delivered on 1 February 1996 (London: School of Oriental and African Studies, University of London, 1997), 5 .

Sims-Williams, 29o3; Shaykh al-Islam al-Wāiz, Faḍāil-i Balkh, 31-32. Mihragān is an ancient Iranian festival dedicated to Mithra/Mihr. Jean Calmard, "Mihragān," in Encyclopaedia of Islam, 2nd ed. (Leiden: Brill), http://dx.doi.org/10.1163/1573-3912_islam_COM _o734. This may imply that there was an important Zoroastrian community in the city but it might be that these were Buddhists who nonetheless participated in traditional Iranian festivals.

24 al-Ya'qūbī, Buldān, 116.

25 al-Balādhurī, Futūh, 409.

26 al-Yacqūbī, Buldān, 287. Țarkhān is, in fact, a title not a name. It is not clear to which historical figure Ya'qūbī is referring here. Peter Golden, "Ṭarkhān," in Encyclopaedia of Islam, 2nd ed. (Leiden: Brill), http://dx.doi.org/10.1163/1573-3912_islam_SIM_7417.

27 al-Ṭabarī, Ta'rīkh, 1:269o, 2891, 2903.

28 al-Tabarī, 2:156. The Arabic aghlaquha literally translates as locked, but means they rejected Muslim authority. 
in the city who wielded considerable power. ${ }^{29}$ In 86/705 Qutayba b. Muslim (d. 96/715) was met by the ispahbadh of Balkh and some local dignitaries, and in 9o/708-709 the ispahbadh of Balkh is said to have been one of the local rulers to whom Nizak Tarkhān wrote when he was trying to unite the local aristocracy of Tukhāristān in resistance to the advances of Qutayba b. Muslim. The barmak (keeper of the Naw Bahār) appears to have been one of the leaders of this revolt as well, and his wife was taken prisoner. ${ }^{30}$ In response Qutayba sent a garrison of 20,000 men to winter at al-Barūqān, near Balkh, presumably to prevent the rebels using the city as a base for operations against the Muslims.

As elsewhere in Tukhāristān, Nizak's defeat led to the imposition of more direct Muslim rule. The ispahbadh is heard of no more and the district was entrusted to Qutayba's brother 'Amr. It seems to have become something of a stronghold of the Qutayba family and 'Amr continued in charge even after his brother's defeat and disgrace in 96/715. In 106/724 'Amr defended the city and its fortress against the troops of Nașr b. Sayyār (d. 131/748) in one of the increasingly fierce tribal conflicts which dominated the last decades of Umayyad rule. ${ }^{31}$ The fact that there was now faction fighting between Yaman and Qays/Mudar in the Balkh, like in the rest of the empire in that period, suggests that there was a significant Arab population.

According to al-Ṭabarī, the next year a new governor, Asad b. 'Abd Allāh alQasrī (governor of Khurāsān, 106-109/724-7 and 117-120/735-738) decided to move the Arab settlers from Barūqān to the madinna (city) of Balkh, and began the rebuilding of the city, ordering the barmak to take charge of the operations. The madina at this stage probably refers to the Bālā Hiṣār. Asad used it as the base for his military operations in $108 / 726-727$, and he is said to have preached from the minbar in Balkh, implying that there was a masjid al-jämi in the city by this stage. ${ }^{32}$ The Fad äil Balkh places the move of the Arab settlers into the city in $118 / 736-737$, and credits Asad with building a congregational mosque in the same year. ${ }^{33}$

The location of this mosque is problematic and the question is closely bound up with the role of Bālā Hișār in the early Islamic period. We know from

29 Although Muslims are described with pre-Islamic titles and titulature in the papyri after the conquest of Egypt, in this context the ispāhbādh must be Persian official given that we can find no example of a Muslim having this title in the Persianate world.

30 al-Ṭabarī, Ta’̀īkh, 2:1181, 1206-1207, 1219; Shaykh al-Islam al-Wāìu, Faḍāil-i Balkh, 34.

31 Shaykh al-Islam al-Wāiz, 2:1472-1477.

$3^{2}$ al-Tabarī, Tảīikh, 2:1500-1501.

33 Shaykh al-Islam al-Wāizu, Faḍāil-i Balkh, 33-35. 
epigraphic and documentary evidence ${ }^{34}$ that the city was the center of an Achaemenid satrapy and it is possible to surmise, by analogy with the more securely dated example at Merv, that the arg and the Bālā Hiișār date, at least in their general layout from the Achaemenid period. Was the Bālā Hiiṣār in fact the setting of the mosque and the sūqs which surrounded it? The madina was described by al-Iștakhrī in the tenth century as being half a farsakh by half a farsakh (ca. three by three kilometres), though it is not clear whether a round or rectangular space is meant, and surrounded by walls made of mud-brick. He also records that the masjid al-jämic was in the middle of the city (madina) not in the rabad and was surrounded by the süqs. ${ }^{35}$ This suggests that the site of the mosque was in the middle of the Bālā Hiișār. This identification is supported by the comment of al-Muqaddasi that one went down into the mosque on steps (yanzalu ilayhi bi-darajin) from the street level. ${ }^{36}$ This could make sense if the mosque was in the raised Bālā Hisạār, since if it were on the flat plain it would be beneath the water table. It may suggest, like the Mogaki Attari in Bukhara, to which one also descends, that it may have occupied the site of an existing, pre-Muslim religious building. On the other hand, the Bālā Hiișār is only about one kilometer in diameter, significantly smaller than the half farsakh (ca. three kilometers) mentioned by al-Iștakhrī. Elsewhere, however, al-Muqaddasi describes streams running along the streets, which cannot be in Bālā Ḥișār. Ibn Bațtūța, who found the city effectively deserted, saw the ruins of a mosque which was about the size of the (huge) mosque of Rabat (Morocco) "but more beautiful." ${ }^{77}$ The archaeological explorations of the 195 os and especially Gardin's survey of the ceramics, came to the conclusion that the Bālā Hiișār may have suffered "une longue période d' abandon"38 from the time of the Muslim conquest, if not before, down to the Timurid period (1370-1507) when the old walls were reused to form the foundations of the new Timurid ramparts. However, the latest reports note laconically "céramique, verres, mon-

34 Besenval and Marquis reported the finding of Achaemenid ceramic material in the Bālā Ḥișār, in "Les travaux de la délégation archéologique française en Afghanistan (DAFA): résultats des campagnes de l'automne 2007-printemps 2008 en Bactriane et à Kaboul,' (note d'information)," Comptes Rendus des Séances de l'Académie des Inscriptions et BellesLettres 152, no. 3 (2008): 98 o.

35 al-Ișțakhrī, Masālik, 278.

36 al-Muqaddasī, Ahsan al-taqāsim, 302.

37 Ibn Baț̣ūṭa, Riḥla, trans. Charles-François Defrémery and Adrian D.H. Bivar as: The Travels of Ibn Battūtata, A.D. 1325-1354 (Cambridge: Published for the Hakluyt Society at the University Press, 1958-2000), 3:572.

38 Le Berre and Schlumberger, "Troisième partie - Observations," 75. 
naies ... attestant d' une forte densité d' occupation du site du IX au XI I siècle."39 The investigation, and hopefully the resolution of this question is fundamental to our understanding of the historical topography of the city.

In 118/736 Asad, governor for the second time, decided to move the administrative capital of all Khurāsān from Merv to Balkh, transferring the dīwāns to the city and building strongholds (ikhtakha al-mașānic). ${ }^{40} \mathrm{~A}$ castle (qal'a) is mentioned in the Umayyad-period city, as are slave markets. ${ }^{41}$ The castle is called a qașr in the Fadā'il-i Balkh and quhandiz in al-Ya'qūbī's account of the wars (involving who?) during the governorate of Nașr b. Sayyār, immediately before the Abbasid revolution, when Nașr imprisoned one of his enemies in it. $^{42}$ We also hear of 2,00o troops raised from the people of Balkh in 118/736. ${ }^{43}$ If, as seems likely, these were Muslims it would imply a Muslim population of the city of at least 10,000 by this time.

In the light of this admittedly fragmentary data it is possible to suggest a history of the first Muslim settlement in Balkh. Despite the repeated "conquests" of the city in the Rāshidūn and Umayyad period, there is no evidence of the establishment of a Muslim garrison in the city. Authority in the city remained in the hands of the ispahbadhs in some sort of partnership with the barmak of the Naw Bahar Buddhist temple and monastery. This position changed in the aftermath of the defeat of Nizak's rebellion in 9o/708-709 when the ispahbadh disappears and Muslim troop were settled, not, it would seem in the old city center of Balkh, but at Barūqān, possibly a Muslim new settlement. Probably in 107/725-726 Asad b. 'Abd Allāh transferred the Arab settlers from Barūqān to the old site of Balkh and this may have represented the first Muslim settlement on the site which was followed by the construction of the mosque in the center of the town. The Fadäil-i Balkh states, however, that this was not the first mosque of Balkh, having been preceded by an 'old mosque' (masjid-i 'atiq ) constructed seven years earlier. ${ }^{44}$ Muslim settlement may also have been estab-

39 Besenval and Marquis, "Les travaux," 982.

40 al-Tabarī, Ta’rīkh, 2:1591. Mașna can mean a fortress, a synonym for qașr but it can also be an open cistern for water. See Edward W. Lane, Arabic-English Lexicon (London: Williams and Norgate, 1863-1893), sv. șn'.

al-Tabarī, Ta'rīkh, 2:1589, 1599; also for use of qal'a in Ghaznawid period in the forthcoming Balkh, 'Mother of Cities.'

Shaykh al-Islam al-Wā'iz, Fậā̄il-i Balkh, 36 ("[Ja'far b. Muhammad b. al-Ash'ath, n/d] built a castle [in Balkh], and ordered a prison to be demolished, and next to it he ordered the building of a college"). The text also refers to "many castles and forts" in the outlying areas of Balkh (p. 5o); al-Ya'qūbī, Buldān, 302.

43 al-Ṭabarī, Ta'rīkh, 2:159o.

44 Shaykh al-Islam al-Wāiż, Faụāill-i Balkh, 35 . 
lished outside the Bālā Ḥișār in the area enclosed by the walls described by the archaeologists as 'Bactres 1A.' In 118/736 the Islamicization of the city continued when Asad b. 'Abd Allāh made Balkh the capital of the whole of Khurāsān and we can suggest that there was by this time a Muslim population of some 10,00o. It seems as if the Muslim settlement was, as in Bukhara, inside the madina/shahristān, possibly at the expense of those inhabitants who chose not to adopt the new faith. ${ }^{45}$ What remains unclear is when the various sections of the rabad were constructed, but Ya'qūbì's account makes it clear that the rabad was enclosed by a wall in his time (late ninth century) and that the Naw Bahār, here described as the residences (manäzil) of the Barmakids - the dynasty that descended from the barmaks of Naw Bahār and wielded great power in the 'Abbāsid court of Hārūn al-Rashīd (r. 170-193/786-8o9) - was to be found there. ${ }^{46}$

\section{4}

Balkh and the Muslim Settlement of Khurāsān and Transoxania

How does Balkh fit into the general pattern of urban development in Khurāsān and Transoxania in the three centuries which followed the Muslim conquests? As is well known, the cities of Central Asia usually had a bipartite or tripartite form. There was usually a fortified citadel (arg/erk), generally circular or oval in form which is either adjacent to, or separate from, a walled inner city (madīna/shahristān). Beyond the inner city lay the suburb (rabad) which was often walled as well. Finally some oases (Balkh, Bukhara) are known to have had very long walls which enclosed the whole cultivated area of the oasis and its villages. Such outer walls, which in Balkh was up to 72 kilometers in length, can hardly have been defensive but used rather to prevent blowing sand and dust from encroaching on the cultivated area and to prevent the flocks of the nomad peoples of the desert from invading the farmed area.

Although many similar forms can be found in different cities, the dating and distribution of these elements seems to have varied greatly. In the best known of the cities, Merv, the round citadel, Erk Kala, seems to date back to the Achaemenid occupation from the fifth century BCE onwards. While the rectangular wall of the city dates back to Seleucid times and was maintained and

45 Hugh Kennedy, "The Coming of Islam to Bukhara," in Living Islamic History: Studies in Honour of Professor Carole Hillenbrand, ed. Yasir Suleiman (Edinburgh: Edinburgh University Press, 2010), 77-91.

46 al-Ya'qūbì, Buldān, 117. 
rebuilt throughout the Sasanian period, the ancient citadel lies on one wall of the shahristān, effectively allowing direct access to the city, along the south side, and to the oasis on the other. ${ }^{47}$ In Samarqand, the citadel lay at the north edge of the fortified city, separated from the rest of the shahristān by deep ditches. ${ }^{48}$ By contrast it seems that the citadel in Bukhara, much smaller than the one at Merv, only dated from the first centuries of the common era. Here the shahristān, again with sub-rectangular walls, was separated from the citadel by an open area which was only built up in the early Islamic period. ${ }^{49}$ In Balkh we seem to have an $\arg$ which lay on the southern wall of the shahristān. ${ }^{50}$ Gardin notes ${ }^{51}$ that the, limited, ceramic evidence makes it clear that the origins of the Bālā Hiișār pre-date the Kushan period and this leads Le Berre and Schlumberger to argue for a Hellenistic origin. ${ }^{22}$ However, the surviving Hellenistic city walls of the region, at Ai Khanum (North-East of Qunduz) and Merv, are clearly rectangular or sub-rectangular in plan while the oval citadel at Merv is firmly dated to the Achaemenid period. By analogy with these more clearly dated sites, it would be possible to argue that the straight south wall of the [rectangular] rabad ('Bactres IA' in Le Berre, et al.) date from the Hellenistic period and there is nothing in the archaeological record to contradict this.

The coming of Muslim rule and Arab settlement in Central Asia occurred in different ways. We are best informed about Merv, from archaeological and textual evidence, and Bukhara, because of the survival of Narshakhï's history of the city, which is extremely interested in topographical information. Narshakhī presented his Tärīkh-i Bukhāra in Arabic in 943-944 to the Sāmānid governor Nuh b. Nașr, and it is the Persian adaptations of the text by Abu Nașr Ahmad Qubawī in 1128-1129 and Muhammad b. Zufar b. 'Umar in 1178-1179 that have

47 For the fortifications in Merv, see Vladimir A. Zavyalov, "Fortifications of the City of Gyaur Kala, Merv," in After Alexander: Central Asia before Islam, eds. Joe Cribb and Georgina Herrman (Oxford and New York: Oxford University Press, 2007), 313-329.

48 Frantz Grenet and Claude Rapin, "De la Samarkand antique à la Samarkand islamique: continuités et ruptures," in Colloque International d'Archéologie islamique, IFAO, Le Caire, 3-7 février 1993, ed. Roland-Pierre Gayraud (Cairo: Institut français d' archéologie orientale, 1998), 387-402.

49 See the discussion in Anette Gangler, Heinz Gaube and Attilio Petruccioli, Bukhara: The Eastern Dome of Islam (Stuttgart: Edition Axel Manges, 2004), 18-22, 30-42.

50 For the best discussion of the walls of Balkh and their dating, see Le Berre and Schlumberger, "Troisième partie - Observations."

$5^{1}$ Gardin, Ceramiques de Bactres, 107.

$5^{2}$ On the grounds that Polybius implies that there was a strong fortress on the site when Antiochus III besieged the king Euthydemos at Balkh. Le Berre and Schlumberger, "Troisième partie - Observations," 87-88. 
survived..$^{53}$ In Merv, the early Muslim settlement was concentrated outside the old shahristān, along the banks of the Majan canal. Until the eleventh century, this new Muslim settlement seems to have been unfortified. By contrast the ancient citadel was in ruins (kharāb) by the mid-eighth century, if not before, and the old shahristān was the center of industrial activity, notably steel making. The first mosque may have been established in middle of the shahristān but later the main mosque, as well as the dār al-imāra of Abū Muslim, were to be found in the unfortified Muslim new town. ${ }^{54}$ The explanation for the abandonment of the huge ancient fortifications of Merv may be perhaps that there were no more attacks expected. It may also have been a consequence of the financial and material difficulty of keeping up and indeed providing a fortification that does not have natural resources.

In Samarqand, by contrast, the new centers of Muslim power, mosques and the dār al-imāra were established on the site of the ancient citadel, appropriating the ancient centers of power. ${ }^{55}$ The explanation for these differences may lie in the nature of the conquests. Merv seems to have been taken more or less peacefully, meaning that the existing inhabitants were allowed to retain their houses and places of worship in the shahristān. The Muslims were therefore obliged to create a new settlement for themselves. Samarqand was conquered as the result of a violent struggle and, at least for a time, the inhabitants were driven out of the city and forbidden to re-enter it on pain of death. It is likely, therefore, that the citadel and fortified city became a largely Muslim environment from an early stage. There is no evidence at Samarqand of an extensive rabad or Muslim new town before the Mongol conquests of the thirteenth century. In Bukhara, the arg remained in the residence of the local rulers of Bukhara, the Bukhār Khudāts at least until the early Abbasid period. ${ }^{56}$ The Arab settlers and the Muslim governors established themselves in the shahristān.

53 Narshakhī, Tārīkh-i Bukhārā, ed. Mudarris Raḍawī ([Tehran]: Intishārāt-i Bunyād-i Farhang-i Īrān, 1351/1971), trans. Richard Frye as: The History of Bukhara (Cambridge, MA: Mediaeval Academy of America, 1954).

54 See Hugh Kennedy, "Medieval Merv: An Historical Overview," in Monuments of Merv, ed. Georgina Herrmann (London: Society of Antiquaries of London, 1999), 25-44.

55 See Grenet and Rapin, "De la Samarkand antique."

56 Kennedy, "The Coming of Islam," 77-91. At the time of the first Arab raids on Bukhara in 54/674, the local ruler was the widow of the Bukhār Khudār Bīdūn. She ruled as regent for her infant son, Ṭughshāda. The Bukhār Khudāt appears again in al-Ṭabarī's account of Qutayba's conquest of Bukhāra in 91/710, after which Qutayba installed the same Țughshāda as the princely ruler of Bukhārā. Vasily V. Barthold and Richard Nelson Frye, "Bukhara," in Encyclopaedia of Islam, 2nd ed. (Leiden: Brill), http://dx.doi.org/10.1163/1573 -3912_islam_SIM_15o8. 
The first mosque seems to have been built in the citadel shortly after the conquest, but in the early Abbasid period a new mosque was constructed in the developing area between citadel and the shahristān where the Kalyon mosque is today. Bukhara also provides the only clear evidence we have for the conversion of a pre-Muslim, either Zoroastrian or, less likely, Buddhist place of worship into a small mosque, the so-called Mogaki-Attari. ${ }^{57}$

How then does Balkh fit into this matrix? It seems likely that there was a continuity of indigenous élite settlement in the fortified area of the Bālā Hișār but until more extensive archaeological mapping and survey work has been carried out in the area this cannot be proved. The function, and indeed the continuing existence of the quhandiz, cannot be proved beyond the end of the Umayyad period. Did it, like the citadel at Samarqand remain the center of power for the new Muslim rulers, was it like the $\arg$ at Merv, abandoned and kharāb, or was it where the local rulers remained like in Bukhara? As for the rabad, it is clear that it, or at least parts of it, were enclosed by fortifications before the Muslim conquest and that these fortifications may date back, as the Merv ones do, to the Seleucid period. What remains quite unclear is whether the rabad area expanded in the aftermath of the Muslim conquest? Did the population expand, as it clearly did in Merv and Bukhara? All these questions remain to be investigated: only after further research in the textual resources and above all the archaeological material, will we be able to understand early Islamic Balkh in the way we can, or think we can, in the other great ancient cities of the region.

Three features within the rabad of Balkh deserve further elaboration, the Naw Bahār, Tepe Zargarān and Nuh Gunbad. The Naw Bahār is probably best described by Ibn al-Faqīh (d. after 292/905). The Naw Bahār was more than a temple and monastery: it was a vast estate. Thus, writes Ibn al-Faqīh (fl. 289/902), the Naw Bahār [estate] comprised an area of 8-by-4 farsakhs ( 48 by 24 kilometres) [in the more detailed Mashhad manuscript the area is given as 7 farsakhs in diameter, which is perhaps seven square farsakhs, so 42 by 42 kilometres]. This would mean that the Naw Bahār territory covered at least twothirds of the Bactran oasis, if not all of it. ${ }^{58}$ Flags were flown on top of the cupola

57 Narshakhī, The History of Bukhara, 21, where the mosque is called the mosque of Mākh.

$5^{8}$ Ibn al-Faqīh, Buldān, 322-324; and the facs. ed. of the Mashhad ms contained in Collec- 
of its central building, which in some languages (i.e. other than Arabic) was known as 'al-ustūn.' Ibn al-Faqīh's description, probably unbeknownst to him, provides clues that make the Buddhist use of Naw Bahār unquestionable. The flying of flags on the cupola is a common feature in Buddhist temples, and ' $a$ ustūn' is orthographically similar to al-ustūp, the Arabicised rendering of the Sanskrit stupa. Round arches and three hundred-sixty prayer cells surrounded the site in which devotees carried out their (monastic) services and slept. The cupola measured one hundred cubits in circumference (i.e. 45.72 meters), and one hundred cubits (45.72 meters) in height. ${ }^{59} \mathrm{Ibn}$ al-Faqīh's account complements the observations made by the Buddhist pilgrim Xuanzang (fl. 630-64os AD). The Chinese visitor would have known a Buddhist site if he had seen one. ${ }^{60}$ Judging from Xuanzang's account, Bactra's landscape was dotted with Buddhist convents that totaled one hundred, and three thousand monks were lodged in them; Naw Bahār was by far the largest. Probably the very stupa mounds inventoried by Warwick Ball in 1982 throughout the Balkh region are the remains of what must have been a comely sight of glistening cupolas dotting the landscape ${ }^{61}$ A mud-brick site known today as Tepe Rustam outside the southern wall of Balkh appears to be the Naw Bahār cupola. It is conceivable that the Naw Bahār functioned as a semi-autonomous Buddhist administrative entity with a remit that extended into the secular domain. By the account of Ibn alFaqīh, the Naw Bahār territory covered two-thirds of the Bactran oasis, which begs the question of whether it functioned as a city within a city. ${ }^{62}$

tions of Geographical Works, 321-324. Xuanzang who travelled in Balkh in the 63os A.D. had estimated the cupola to stand about 200 feet (6o metres) high. Xuanzang, Si-Yu-Ki: Buddhist Records of the Western World, trans. Samuel Beal (London: Trübner \& Co., 1906), 1:46.

59 Xuanzang, 1:46.

6o Xuanzang, 46. Xuanzang noted that the monks of Naw Bahār studied the religious teaching of the Shravakayāna, which he refers to by the pejorative name Hinayāna ('lesser vehicle'). This is a reference to early forms of Buddhism. Richard Gombrich, Étienne Lamotte and Lal Mani Joshi, "Buddhism in Ancient India," in The World of Buddhism, eds. Heinz Bechert and Richard Gombrich (London: Thames and Hudson, 1984), 77-89.

61 Ball records stupa sites in the eastern Balkh area called Charkh-i Falak, Āsyā-yi Qunak and Chihil-dukhtarān sites. The Charkh-i Falak is located five kilometers east of old Balkh on the old route to Mazār-i Sharif. It consists of the remains of a mud-brick stupa - a cylindrical drum on a square base, and there are many more ruins southwards of the site. The Āsyā-yi Qunak $5 \mathrm{~km}$ southeast of old Balkh has a very high narrow circular mound of mud eighteen meters high and resembles a stupa. There are many ruins in its vicinity. The Chihil-dukhtarān site, three kilometers southeast of old Balkh and near the Āsiyāyi Qunak, is a large irregular mud-brick structure that may be a stupa as well. See Ball, Archaeological Gazetteer, no. 191, 72.

62 For more details, see Étienne de la Vaissière, "De Bactres à Balkh, par le Nowbahar," 
We do not know how long the temple site served as a place of worship after the Islamic conquest. While al-Balādhurī has Naw Bahār's Buddhist stupavihara complex destroyed during the campaigns under the caliph Mu'āwiya (r. 41-6o/661-68o), ${ }^{63}$ al-Ṭabarī reports that Nizzak Tarkhān went to pray there during his rebellion against Qutayba b. Muslim in 9o/709. ${ }^{64}$ The anonymous Hudūd al-ălam describes the royal buildings (bināhā-yi khusrawān) and the remaining Naw Bahār's decorations, including painted images (naqsha) and wonderful works (kärkard). ${ }^{65}$ These are presumably secco or fresco murals and carvings on the temple's plastered walls that had survived into the author's time. The Fadāilli Balkh does not mention a Buddhist function, which would indicate that at the latest by the twelfth century the Buddhist meaning of Naw Bahār had been lost. This 'devilish' house only occupied the realms of a rude past, not the cityscape of the present. ${ }^{66}$ Thus, two-thirds of Balkh had been effectively managed by the barmak at least until the time of the Muslim conquest. No king or local ruler is mentioned otherwise, which can only add further evidence to the observation that most of Balkh was in fact Naw Bahār. ${ }^{67}$

Naymark and Kennedy have observed in the early Islamic period the merging of smaller urban settlements or principalities into wide unfortified agglomerations covering the former rural territory. ${ }^{68}$ In Balkh, too, Naw Bahār is no longer mentioned as an administrative entity. Al-Ya'qūbī's account implies the 'demotion' of Naw Bahār from a de facto temple-city to a mere section in Balkh's rabad..$^{69}$ Naw Bahār had been merged into the wider Balkh city or 'metropolis'

Journal Asiatique 298, no. 2 (2010): 517-533; Arezou Azad, Sacred Landscape in Medieval Afghanistan: Revisiting the Fadă āil-i Balkh (Oxford: Oxford University Press, 2013), 68-110.

63 al-Balādhurī, Futūh, 409. Al-Ṭabarī does not raise any tensions regarding the Naw Bahār or Balkh for this period, contending that al-Rābi ' b. Ziyād al-Hārithī was the governor of Khurāsān and "conquered Balkh peacefully, they had closed it after Ahnnaf b. Qays made peace with them." See al-Ṭabarī, Ta'rīkh, 2:156.

64 al-Ṭabarī, 1205.

65 Anonymous, Hudūd al'ālam, 311.

66 Shaykh al-Islam al-Wāiz, Fadä'il-i Balkh, 46: "It is attributed to Ibn Shawdhab that the devil (iblīs) has his temple (khāna) in Khurāsān and they call it Naw Bahār. Every year he makes a pilgrimage to that temple."

67 Reference to a king or other ruler (besides the barmāk) are also not found in Turkic sources. See: De la Vaissière, "De Bactres à Balkh."

68 Aleksandr Naymark, "The Size of Samanid Bukhara: A Note on Settlement Patterns in Early Islamic Mawarannahr," in Bukhara: The Myth and the Architecture, ed. Attilio Petruccioli (Cambridge, MA: Aga Khan Program for Islamic Architecture at Harvard University and the Massachusetts Institute of Technology, 1999), 45-46; and Kennedy, "From Shahristan," 30-33.

69 al-Ya'qūbī, Buldān, 117: "wa fì l-rabạ̣ al-Naw Bahār." 
(Ar. mișr), to borrow a term used by al-Muqaddasī, which can be considered synonymous with the medieval Persian shahr. ${ }^{70}$

The second feature of the rabad is a surviving freestanding building which has been attributed to the early Islamic period, possibly even to the Umayyads, known as the Nuh Gunbad (known locally as "Hajjī Piyāda"). ${ }^{71}$ The remains of the nine-domed structure with beautifully carved columns stand three kilometers outside the southern wall of Balkh. ${ }^{72}$ Its extra muros location supports the argument for a newly fashioned city spread over a wider urban settlement. Various scholars have written about the site, contending that it was a mosque. However, none of the Arab geographers mention it, and the Fad àil-i Balkh only mentions the 'Nuh Gunbadān' in passing without specifying that it might be a masjid. ${ }^{73}$ The Fad̄äill-i Balkh is usually meticulous about identifying the

70 Al-Muqaddasī defines the specialized vocabulary of his science specifically for jurists who would need to take into account jurisdictional boundaries. At the highest level, the head of the province (iqlìm, pl. aqālim) is the mișr, or 'metropolis.' It administers over districts (kawra), themselves containing several main towns (madina, pl. mudun) around a capital (qașaba). Exceptions occur inter alia in al-mashriq, which has two metropoles divided by the Oxus (Abū Zayd al-Balkhī had divided the region into three - Khurāsān, Sīstān and Māwarā' al-Nahr). A mișr can be a capital of its district, but a capital is not necessarily a mișr; and a mișr gives its name to a district. Balkh is the name of the capital (qașaba) of Balkh district (kawr). See al-Muqaddasī, Aḥsan al-taqāsīm, 47, 26o, 295-296; trans. Collins, Best Divisions, 51, 236, 261; also André Miquel, "al-Muḳaddasī," in Enyclopaedia of Islam, 2nd ed. (Leiden: Brill), http://dx.doi.org/10.1163/1573-3912_islam_SIM_5451. Regarding the Persian terms, Aubin points out that the Persian use of shahr such as in shahr-i Kirmān in mediaeval texts, which does not distinguish between the vast territory it encompasses and the principal locality, has skewed some of the scholarship. Thus, shahr can refer to a city and the canton (nähiyat) which surrounds it, while also being the "chef-lieu de la province." Shahr and the Arabic mișr, therefore, have the same meaning. See Jean Aubin, "Eléments pour l'étude des agglomerations urbaines dans l' Iran medieval," in The Islamic City: A Colloquium, eds. Albert Hourani and Samuel Miklos Stern (Oxford: Bruno Cassirer, 1970), 68-69. The Persian equivalents appear in the Fad̄àil-i Balkh as well.

71 For the first art-historical reports on the site, see Golombek, "The Abbasid Mosque," 173189, and Galina Pugachenkova, "Nuh Gumbed v Balkhe," Sovetskaia Archeologiia 3 (1970): 241-250. They superseded the article by Asadollah Melikian-Chirvani, "La plus anciènne mosquée de Balkh," Arts and the Islamic World 20 (1969): 3-20.

72 The floor plan was provided by Pugachenkova in "Nuh Gumbed," 241-250; and has been reproduced by various scholars. Golombek identified the stucco carvings, a distinctive style with a vocabulary of motifs consisting of grape-leaves, vine scrolls, palmettes and fir-cones, as being best represented in Samarra, the Iraqi city $125 \mathrm{~km}$ north of Baghdad founded by the Abbasid caliph al- Mu'tasim (r. 218-227/833-842). See Golombek, "The Abbasid Mosque," 177. See also the Masjid-i Chahār Sutūn at Tirmidh. It has the same ninedomed floor plan.

73 A nuh gunbadān is mentioned in the Fadă ${ }^{2} i$ - $i$ Balkh as the site adjacent to which stood the shrine of the Shaykh al-Islām al-Nuṣayrī/al-Nașirī (no. 53, d. 411/102o), states the author of 
mosques of Balkh as masjid, and it would be odd to leave out such a beautifully decorated one from the extensive list of mosques mentioned. ${ }^{74}$

Why then would it not do so in relation to the Nuh Gunbad/Hajji Piyāda site? The answer seems to lie in the negative literary and archaeological evidence: there is no evidence that the Nuh Gunbad was a mosque in the eighth century. Recent excavations have unearthed a mihrāb, however, the date of the mihrāb is still not determined with any certainty (and it may well post-date the Fad ẫil-i Balkh). ${ }^{75}$ Scholars have found that the architectural model based on four columns at the axes of a central square, surrounded by an outer wall, thus forming nine roofing elements covered in domes, has pre-Islamic precedents. On the other hand, the architectural style is found in early Iranian mosques, such as at Kerman as well. Perhaps the style had survived not only in the form of a mosque but as part of a palatial building type as well.

What remains relevant for our analysis is the tentative dating of the structure to the eighth-ninth centuries, and the use of pre-Islamic models for Islamicperiod buildings - whether for religious or ceremonial purposes - within a program of developing the wider city (Per. shahr) of Balkh.

The Nuh Gunbad is by no means the only freestanding medieval structure in the Balkh area. Galina Pugachenkova in the 196os inventoried and photographed a number of eleventh-century commemorative tomb structures outside the walls of Balkh. ${ }^{76}$ The eleventh-century Bābā Ḥătim shrine structure forty kilometers west of the medieval Balkh site attracted the attention of Asadollah Melikian-Chirvani, Janine Sourdel-Thomine and Adrian D.H. Bivar in the late 196os and 1970s. An impressive Kufic dedicatory border inscription around the shrine's doorway references the patron, a certain Sālār Khalīl, as well as his female ancestors. The language is Arabic, albeit in Persianised grammar. $^{77}$

the Kitāb al-bahja cited in the Fad̄ẩil-i Balkh. The site was located at a place called panj rish ('five beards'). See Shaykh al-Islam al-Wāiz, Faḍ̄àil-i Balkh, 320. Today there is a small cemetery shaded by willow trees across from the Nuh Gunbad.

74 Shaykh al-Islam al-Wāìz, Faḍāill-i Balkh, 207. For a fuller list, see Azad, Sacred Landscape, 88-89.

75 Adle, "Communication," $589 \mathrm{ff}$.

76 Galina Pugachenkova, "Little Known Monuments of the Balkh Area," Art and Archaeology Research Papers 13 (1968): 31-40.

77 Asadollah Melikian-Chirvani, "Remarques préliminaires sur un mausolée Ghaznévide," Arts Asiatiques 17 (1968): 59-92; Janine Sourdel-Thomine, "Le mausolée dit de Baba Hatim en Afghanistan," Revue des études islamiques 39 (1971): 293-320; Adrian D.H. Bivar, "The Inscription of Sālār Khalīl in Afghanistan," Journal of the Royal Asiatic Society 2 (1977): 145-149. The inscription reads: bi'smi 'llāhi 'l-rahmāni 'l-raḥim hādhā (al-)mashhad Sāāarr Khalīl-i Sayyid sana'ahu li-ummi ummih [barra] da 'llāhu madja'ahumā wa-nawwara hafa- 
The third feature of the rabad is the mound (tall) of Tepe Zargarān (noncontiguous part of 'Bactres I' and 'Bactres IA') on the eastern limit. Today it stands as a limestone mound ( 900 metres by 300 metres), smaller than the Bālā Hișār, and extending horizontally over several dozen meters. It is located to the east of a serpentine wall. Excavated remains, such as pre-Islamic column bases and pillars depicting bovine creatures, date back to the Kūshān and Sāsānian periods. ${ }^{78}$ Schlumberger found ceramic sherds in Tepe Zargarān bearing Sogdian and Kharoshti inscriptions, as well as Kūshān and Sasanian coins. ${ }^{79}$ Gardin identified glazed polychrome ceramics dating to the ninth to the twelfth centuries here.$^{80}$ More recent excavations have unearthed coins and ceramic pots from the Islamic period which Balkh Art and Cultural Heritage (вАСн) numismatists have concluded indicate that the occupation of this part of the city might have continued to the tenth century. They found, with one exception, no coins that relate to the final period before the Mongol destruction. ${ }^{81}$

What was the function of Tepe Zargarān? Might it have served as a cult or pilgrimage site? Its location away from the center of town begs the question whether it was an isolated site, or whether it was embedded within a settled suburb. Linking the literary evidence to this tall is far from straightforward. An important mound is known as Tall-i Gushtāsp/Vishtāsp ('Mound of Gushtāsp/Vishtaspa') to the Fad̆ äill-i Balkh. It served as a sacred place and the burial site of several prominent figures, including the prophet Job, the mythical king Gushtāsp, and a number of the saints of Balkh. ${ }^{82}$

After the arrival of Islam, it is possible that Tepe Zargarān provided the eastern limit for an extended inner city (i.e. beyond the serpentine wall), while it may also have served as a non-contiguous religious site. We have accounts that

ratahuma ("In the name of God, the Merciful, the Compassionate. This mausoleum, the Commander Khalil the Sayyid designed it for the mother of his mother. May God cool the resting-place of both of them, and illuminate their sepulchre.") The site was subsequently restored - see Régis de Valence, La Restauration du mausolée de Baba Hatim en Afghanistan (Paris: Editions Recherche sur les civilisations, 1982).

78 Ball, Archaeological Gazetteer, 1:47-49; Roland Besenval, Rapport d'activités (Kabul, La Délégation archéologique française en Afghanistan, 2007). The pillars and capitals were viewed by the author in Balkh on 23 July 2009 both at the Tepe Zargarān site and in the offices of the Balkh Province's Culture and Information Department in Mazār-i Shariff.

79 Schlumberger, "Prospection archéologique," 181-184, and figs. 12 and 13.

8o Gardin, Céramiques de Bactres, 87-97, 23-28, 42-43, 53, 89 (fig. 32), 119-120 (coins), plate XXIV.

81 Stefan Heidemann and Matthias Naue, "Coin Finds in Relation to Local History," unpublished report for the Balkh Art and Cultural Heritage Project (2013), 31. A detailed chapter on this will appear in the BACH volume, Balkh, 'Mother of Cities'.

82 Further details, see Azad, Sacred Landscape, 72-75, 96-97. 
the top of a conspicuous mound (sar-itall) was used as a burial ground for ninth and tenth-century Islamic legal scholars, and it is plausible that the reference is to Tepe Zargarān. If this is the case then we have an example of how the Muslims appropriated sacred spaces of the conquered peoples, and converted them into Islamic spaces.

\section{6}

\section{Conclusion}

The history of the coming of Islam to Balkh remains much less well understood than that of other major Central Asian cities like Marv, Samarqand and Bukhara. This is partly because of the paucity of early literary sources, partially compensated by the thirteenth century Fadäil-i Balkh but more significantly by the lack of sustained archaeological investigation of the Islamic city of the sort that was done in Soviet and post-Soviet times in the other great cities. Nonetheless, certain features and developments can be made out. The central role of the pre-Islamic Bala Hisar which incorporated the citadel seems to have been the main centre of the city, the shahristann, until at least the twelfth century and may have been the site of the lost great mosque, admired by the Arab geographers. However, there is no evidence that the citadel played a major part in urban life. We can suggest that in early Islamic times the city spread with the construction of the rabad outside the walls of the Bala Hisar at a lower elevation, and again outside the walls of the rabad. This swallowed up the great stupa of the Nawbahar and was the site of the only important surviving early Islamic building of Balkh, the controversial Nuh Gunbad. The development of the extra-mural rabad in this period suggests a pattern of urban development in Balkh broadly similar to that in Marv, Bukhara and Paykent which all acquired rabads during this period, rabads which in Marv and Bukhara, were the location of the main religious buildings and the main commercial quarters. Only with more sustained archaeological work, will we be able to improve on these tentative conclusions.

While the main focus of this study lies with the city of Balkh, connections with the surrounding countryside are obvious and significant. The town's hinterland formed a source of supplies for the city with agricultural grounds providing staple foods as well as seasonal fruits and vegetables. Pastoral grounds extending into more remote areas were at least as important for the mobile nomads who provided the city with food stuffs and other supplies such as hides, but who could also be called upon as a military force through temporary and more constant alliances. The city's income consisted of taxes and tolls or fees they could 
raise on the services and transactions thus taking place: commercial, agricultural and military. To maintain such material and personnel services, the city aimed to extend its influence over the surrounding lands by different means. Defense works and the soldiers housed in them were an obvious means by which the city imposed control over its hinterland - this would have helped especially the collection of taxes and other impositions as well as reduce the chance of rebellions and other acts of disobedience. It also points to the other important way through which the city maintained its dominance, namely by offering the surrounding population protection from attacks and opportunities to sell their products. The city's commercial function with an Arab soldier population who could dispense of a spendable salary and the administrative activities as well as the expanding urban population all offered opportunities for agricultural and household manufacture trade as well as long-distance commercial activities. In other words the city attached the inhabitants of the surrounding lands by offering services that were beneficial to them. Also through institutions, legal and religious, did the city play an increasingly central role in the life of the people around. This offered indirect ways of controlling the people and lands around the city.

\section{Bibliography}

\section{Primary Sources}

Anonymous. Hudūd al-ālam. Revised edition. Edited by Maryam Mīr-Aḥmadī and Ghulām-Riḍā Warharām. Tehran: Chāpkhāna-yi Dānishgāh-i al-Zahrā’, 1383/20042005 .

al-Balādhurī, Aḥmad b. Yaḥyā. Futūḥ al-buldān. Edited by Michael Jan de Goeje. Leiden:

Brill, 1866. Translated by Francis C. Murgotten as: The Origins of the Islamic State: Being a Translation from the Arabic, Accompanied with Annotations, Geographic and Historic Notes of the Kitâb Futûh Al-Buldân of Al-Imâm Abū-l 'Abbâs Ahmmad Ibn-Jâbir Al-Balâdhuri. 2 vols. New York: Columbia University Press, 1924.

Bal'amī, Abū 'Alī Muḥammad ibn Muḥammad. Tārīkh-i Bal'amī. Edited by Parvīn Gunābādī and Muhammad Taqī Bahār. Tehran: Kitābfurūshīi Zavvār, 1353/1974.

Bayhaqī, Abū al-Faḍl Muhammad b. Ḥusayn. Tārīkh-i Bayhaqī. Edited by 'Alī Akbar Fayyāḍ. Tehran: Kitābkhāna-yi Millī-yi Īrān, 1383/2004-2005. Translated by Edmund Bosworth and Mohsen Ashtiany as: The History of Beyhaqi: The History of Sultan Mas'ud of Ghazna, 1030-1041. 3 vols. Boston, MA: Ilex Foundation, 2011.

Ctesias of Cnidus. “Persica.” In Photius, Bibliothèque, edited by R. Henry, 1959-1991. Paris: Les Belles Lettres, 1967 .

Gardīzī, Abū Sa'īd 'Abd al-Ḥayy b. al-Ḍaḥhāk. Zayn al-akhbār. Edited by 'Abd al-Ḥayy 
Hạībī. Tehran: Intishārāt-i Bunyād-i Farhang-i Īrān, 1347/1968. Translated by Edmund Bosworth as: The Ornament of Histories: A History of the Eastern Islamic lands AD 650-1041: The Original Text of Abû Sa îd 'Abd al-Hayy Gardīzī. BIPs Persian Studies Series 10. London: I.B. Tauris, 2011.

Ibn Bațutụa. Riḥla. Translated by Charles-François Defrémery and Adrian D.H. Bivar as: The Travels of Ibn Batțūța, A.D.1325-1354. 5 vols. Cambridge: Cambridge University Press, Hakluyt Society, 1958-200o.

Ibn al-Faqīh. Kitāb al-Buldān. Edited by Michael Jan de Goeje. Leiden: Brill, 1967 . Ibn al-Faqīh. Collections of Geographical Works by Ibn al-Faqīh, Ibn Faḍlān, Abū DulafalKhazraji. Facs. Edited by Fuat Sezgin. Frankfurt am Main: Institute for the History of Arabic-Islamic Science, 1987.

Ibn Ḥawqal, Abū al-Qāsim b. 'Alī. Șūrat al-arḍ. Edited by Michael Jan de Goeje. Leiden: Brill, 1873. Translated by Johannes Hendrik Kramers and Gaston Wiet as: Configuration de la Terre. Beirut: Commission Internationale pour la Traduction des Chefsd' œuvre, 1964.

al-Idrīsī, Abū 'Abd Allāh Muhammad b. Muhammad. Description de l'Afrique et de l'Espagne: texte arabe avec une tr., des notes et un glossaire par R. Dozy et M.J. de Goeje (Kitāb Nuzhat al-mushtāq fì ikhtirāq al-āfāq). Leiden: Brill, 1866.

al-Iștakhrī, Ibrāhīm b. Muḥammad Abū Isḥāq. Kitāa Masālik al-mamālik. Edited by Michael Jan de Goeje. Leiden: Brill, 1927.

al-Mas'ūì̄, Abū al-Ḥasan 'Alī b. al-Ḥusayn. Kitab al-Tanbīh wa al-ishrāf, 2nd edition. Edited by Michael Jan de Goeje. Leiden: Brill, 1893-1894.

al-Muqaddasī, Shams al-Dīn Abū 'Abd Allāh Muhammad. Kitāb Aḥsan al-taqāsīm fì ma'rifat al-'aqālìm. Edited by Michael Jan de Goeje. Leiden: Brill, 19o6. Translated by Basil Collins and Muhammad Hamid al-Tai as: The Best Divisions for Knowledge of the Regions. Doha: Centre for Muslim Contribution to Civilization, and Garnet, 1994.

Narshakhī. Tārīkh-iBukhārā. Edited by Mudarris Raḍawī. [Tehran]: Intishārāt-i Bunyādi Farhang-i Īrān, 1351/1971. Translated by Richard Frye as: The History of Bukhara. Cambridge, MA: Mediaeval Academy of America, 1954.

Shaykh al-Islam al-Wā’iz. Faḍāill-i Balkh. Edited by 'Abd al-Ḥayy Habīīì Tehran: Intishārāt-i Bunyād-i Farhang-i Īrān, 1350/1971.

al-Ṭabarī, Abū Jađfar Muhammad b. Jarīr. Ta’rīkh al-rusul wa-l-mulūk. Edited by Michael Jan de Goeje et al. as: Annales quos scripsit Abu Djafar Mohammed ibn Djarir atTabari. 15 vols. Leiden: Brill, 1879-19o1.

al-Ya'qūbī, Abū al-Abbās Aḥmad. Kitāb al-Buldān. Edited by Michael Jan de Goeje. Leiden: Brill, 1892 [186o]. 


\section{Secondary Sources}

Adamec, Ludwig. Historical and Political Gazetteer of Afghanistan: Mazar-i-Sharif and North-Central Afghanistan, vol. 4. Graz, Austria: Akademische Druck- u. Verlagsanstalt, 1979.

Adle, Chariyar. "Communication: la mosquée Hâji Piyâdah/Noh Gonbadân à Balkh (Afghanistan), un chef d'œuvre de Fazl de Barmecide construit en 178-179/794795?" Comptes Rendus des Séances de l'Académie des Inscriptions et Belles-Lettres 2001, no. 1 (2011): 565-625.

Aubin, Jean. "Eléments pour l' étude des agglomérations urbaines dans l' Iran mediéval." In The Islamic City: A Colloquium, edited by Albert Hourani and Samuel Miklos Stern, 65-75. Oxford: Bruno Cassirer, 1970.

Azad, Arezou. "The Fadā̇il-i Balkh and its Place in Islamic Historiography." IRAN - Journal of the British Institute of Persian Studies 50 (2012): 79-102.

Azad, Arezou. Sacred Landscape in Medieval Afghanistan: Revisiting the Fad̄̄alil-i Balkh. Oxford: Oxford University Press, 2013.

Azad, Arezou. "Living Happily Ever After: Fraternal Polyandry, Taxes and 'the House' in Early Islamic Bactria." Bulletin of the School of Oriental and African Studies 79, no. 1 (2016): 33-56.

Ball, Warwick. Archaeological Gazetteer of Afghanistan. 2 vols. Paris: Éditions recherche sur les civilisations, 1982.

Barthold, Vasily Vladimirovich, and R.N. Frye. "Bukhārā." In Encyclopaedia of Islam, 2nd edition. Edited by P. Bearman, Th. Bianquis, C.E. Bosworth, E. van Donzel and W.P. Heinrichs. Leiden: Brill. http://dx.doi.org/10.1163/1573-3912_islam_SIM_1508.

Bernard, Paul, et al. Fouilles d'Ä̈Khānom. Paris: Klincksieck, 1973-.

Bernard, Paul, Roland Besenval and Philippe Marquis. "Du « mirage bactrien » aux réalités archéologiques: nouvelles fouilles de la délégation archéologique française en Afghanistan (DAFA) à Bactres (2004-2005)." Comptes Rendus des Séances de l'Académie des Inscriptions et Belles-Lettres 150, no. 2 (2006): 1175-248.

Berre, Marc le, and Daniel Schlumberger. "Troisième partie - Observations sur les remparts de Bactres." In Monuments Préislamiques d'Afghanistan, edited by Bruno Dagens, Marc Le Berre and Daniel Schlumberger, 41-6o. Paris: Librairie G. Klincksieck, 1964 .

Besenval, Roland. Rapport d'activités. Kabul, La Délégation archéologique française en Afghanistan, 2007.

Besenval, Roland, Paul Bernard and Jean-François Jarrige. "Carnet de route en images d'un voyage sur les sites archéologiques de la Bactriane afghane (mai 2002)." Comptes Rendus des Séances de l'Académie des Inscriptions et Belles-Lettres 146, no. 4 (2002): 1385-428.

Besenval, Roland, and Philippe Marquis. "Les travaux de la délégation archéologique française en Afghanistan (DAFA): résultats des campagnes de l' automne 2007-prin- 
temps 2008 en Bactriane et à Kaboul, (note d'information)." Comptes Rendus des Séances de l'Académie des Inscriptions et Belles-Lettres 152, no. 3 (2008): 973-995.

Bivar, Adrian D.H. "The Inscription of Sālār Khalīl in Afghanistan." Journal of the Royal Asiatic Society 2 (1977): 145-149.

Calmard, Jean. "Mihragān." In Encyclopaedia of Islam, 2nd edition. Edited by P. Bearman, Th. Bianquis, C.E. Bosworth, E. van Donzel and W.P. Heinrichs. Leiden: Brill. http://dx.doi.org/10.1163/1573-3912_islam_COM_o734.

Foucher, Alfred. La Vieille route de l'Inde de Bactres à Taxila. 2 vols. Paris: Les Éditions d' art et d'histoire, 1942-1947.

Fussman, Gérard, and Daniel Schlumberger. Surkh Kotal en Bactriane. Paris: Diffusion de Boccard, 1983-199o.

Gangler, Anette, Heinz Gaube and Attilio Petruccioli. Bukhara: The Eastern Dome of Islam. Stuttgart and London: Edition Axel Manges, 2004.

Gardin, Jean-Claude. Céramiques de Bactres: Mémoires de la Délégation Archéologique Française en Afghanistan XV Series. Paris: Libr. C. Klincksieck, 1957.

Golden, Peter. “Ṭarkhān.” In Encyclopaedia of Islam, 2nd edition. Edited by P. Bearman, Th. Bianquis, C.E. Bosworth, E. van Donzel and W.P. Heinrichs. Leiden: Brill. http:// dx.doi.org/10.1163/1573-3912_islam_SIM_7417.

Golombek, Lisa. “The Abbasid Mosque at Balkh." Oriental Art 15 (1969): 173-189.

Gombrich, Richard, Étienne Lamotte and Lal Mani Joshi. "Buddhism in Ancient India." In The World of Buddhism, edited by Heinz Bechert and Richard Gombrich, 77-89. London: Thames and Hudson, 1984.

Grenet, Frantz, and Claude Rapin. "De la Samarkand antique à la Samarkand islamique: continuités et ruptures." In Colloque International d'Archéologie islamique, IFAO, Le Caire, 3-7 février 1993, edited by Roland-Pierre Gayraud, 387-402. Cairo: Institut français d' archéologie orientale, 1998.

Heidemann, Stefan, and Matthias Naue. "Coin Finds in Relation to Local History." Unpublished report for the Balkh Art and Cultural Heritage Project (2013).

Hillenbrand, Robert. Studies in Medieval Islamic Architecture. 2 vols. London: Pindar Press, 2006.

Kennedy, Hugh. "Medieval Merv: An Historical Overview." In Monuments of Merv, edited by Georgina Herrmann, 25-44. London: Society of Antiquaries of London, 1999 .

Kennedy, Hugh. "From Shahristan to Medina." Studia Islamica 102-103 (2006): 5-34.

Kennedy, Hugh. "The Coming of Islam to Bukhara." In Living Islamic History: Studies in Honour of Professor Carole Hillenbrand, edited by Yasir Suleiman, 77-91. Edinburgh: Edinburgh University Press, 2010.

Khan, Geoffrey. Arabic Documents from Early Islamic Khurasan. Studies in the Khalili Collection, vol. 5. London: Nour Foundation in association with Azimuth Editions, 2006 [c2007]. 
Lane, Edward W. Arabic-English Lexicon. London: Williams and Norgate, 1863-1893.

Litvinskij, Boris. "Kalai-Kafirnigan: Problems in the Religion and Art of Early Mediaeval Tokharistan." East and West 31 (1981): 35-66.

Litvinskij, Boris. The Buddhist Monastery of Ajina Tepa. Rome: Istituto Italiano per l'Africa e l'Oriente, 2004.

Meftah, Elhameh. Jughrāfiyā-yi tārīkh-i Balkh wa Jayḥūn wa muzāâ̄t-i Balkh. Tehran: Institute for the Humanities and Cultural Studies, 1367/1997.

Melikian-Chirvani, Asadollah. "Remarques préliminaires sur un mausolée Ghaznévide." Arts Asiatiques 17 (1968): 59-92

Melikian-Chirvani, Asadollah. "La plus anciènne mosquée de Balkh." Arts and the Islamic World 20 (1969): 3-20.

Miquel, André. "al-Muḳaddasī." In Encyclopaedia of Islam, 2nd edition. Edited by P. Bearman, Th. Bianquis, C.E. Bosworth, E. van Donzel and W.P. Heinrichs. Leiden: Brill. http://dx.doi.org/10.1163/1573-3912_islam_SIM_5451.

Naveh, Joseph, and Shaul Shaked, eds. and trans. Aramaic Documents from Ancient Bactria: (Fourth Century B.C.E.): From the Khalili Collections. London: Khalili Family Trust Publication, 2012.

Naymark, Aleksandr. "The Size of Samanid Bukhara: A Note on Settlement Patterns in Early Islamic Mawarannahr." In Bukhara: The Myth and the Architecture, edited by Attilio Petruccioli, 39-6o. (Cambridge, MA: Aga Khan Program for Islamic Architecture at Harvard University and the Massachusetts Institute of Technology, 1999).

Pugachenkova, Galina. "Little Known Monuments of the Balkh Area." Art and Archaeology Research Papers 13 (1968): 31-40.

Pugachenkova, Galina. "Nuh Gumbed v Balkhe." Sovetskaia Archeologiia 3 (1970): 241250.

Sarianidi, Viktor. The Golden Hoard of Bactria. New York: H.N. Abrams, 1985.

Schlumberger, Daniel. "La prospection archéologique de Bactres (printemps 1947)." Syria 26 (1949): 173-19o.

Schwartz, Florian. Balh und die Landschaften am oberen Oxus: Hurasan III, Sylloge Numorum Arabicorum Tübingen XIVc. Tübingen: Wasmuth Verlag, 2002.

Schwarz, Paul. "Bemerkungen zu den arabischen Nachrichten über Balkh.” In Oriental Studies in Honour of Cursetji Erachji Pavry, edited by Jal Dastur Cursetji Pavry, 434443. London: Oxford University Press, 1933.

Sims-Williams, Nicholas. New Light on Ancient Afghanistan: The Decipherment of Bactrian, An Inaugural Lecture Delivered on 1 February 1996. London: School of Oriental and African Studies, University of London, 1997.

Sims-Williams, Nicholas. Bactrian Documents from Northern Afghanistan, I: Legal and Economic Documents. Revised edition. Studies in the Khalili Collection 3. Corpus Inscriptionum Iranicarum, part. 2, vol. 6. Oxford: The Nour Foundation in association with Azimuth Editions and Oxford University Press, 2012 [c200o, 2001]. 
Sourdel-Thomine, Janine. "Le mausolée dit de Baba Hatim en Afghanistan." Revue des études islamiques 39 (1971): 293-320.

Strange, Guy le. Lands of the Eastern Caliphate. Cambridge: University Press, 1905.

Stronk, Jan. Ctesias' Persian History. Düsseldorf: Wellem, 2010.

Vaissière, Étienne de la. "De Bactres à Balkh, par le Nowbahar." Journale Asiatique 298, no. 2 (2010): 517-533.

Valence, Régis de. La Restauration du mausolée de Baba Hatim en Afghanistan. Paris: Editions Recherche sur les civilisations, 1982.

Wolff, Fritz, trans. Avesta: Die heiligen Bücher der Parsen. Strassburg: Karl J. Trübner, 1910.

Xuanzang [Hsiuen Tsang]. Si-Yu-Ki: Buddhist Records of the Western World. 2 vols. Translated by Samuel Beal. London: Trübner \& Co., $19 \circ 6$.

Young, Rodney. "The South Wall of Balkh-Bactra." American Journal of Archaeology 59 (1955): 267-276.

Zavyalov, Vladimir A. "Fortifications of the City of Gyaur Kala, Merv." In After Alexander: Central Asia before Islam, edited by Joe Cribb and Georgina Herrmann, 313-329. Oxford/New York: Oxford University Press, 2007. 